Original Research Paper

\title{
Skrining dan Edukasi Pencegahan Bullying Pada Siswa SMA Negeri Di Kota Mataram
}

\author{
Emmy Amalia ${ }^{1 *}$, Lina Nurbaiti ${ }^{1}$, Wahyu Sulistya Affarah ${ }^{1}$, Hamsu Kadriyan ${ }^{1}$ \\ ${ }^{1}$ Fakultas Kedokteran, Universitas Mataram
}

*Corresponding Author: Emmy Amalia, Fakultas Kedokteran, Universitas Mataram, Indonesia; Email: emmy.amalia@ymail.com

\begin{abstract}
Abstrak: Bullying telah dikenal sebagai masalah sosial yang terutama ditemukan di kalangan pelajar. Bullying dapat membawa dampak buruk yang berat pada korban termasuk gangguan belajar, gangguan mental, gangguan fisik, dan masalah kesehatan lain. Di beberapa negara, bullying berkontribusi besar terhadap angka kejadian bunuh diri pada remaja. Kebanyakan perilaku bullying terjadi secara tersembunyi (covert) dan sering tidak dilaporkan, sehingga kurang disadari oleh kebanyakan orang. Di Indonesia, Komisi Perlindungan Anak Indonesia (KPAI) pada tahun 2015 merilis data bahwa kasus bullying pernah dialami sekitar 87,6 \% anak dimana korban laki-laki lebih banyak dari perempuan dan perilaku bullying lebih rentan terjadi pada usia remaja awal. Penelitian Sejiwa Foundation pada tahun 2008 menunjukkan bahwa kekerasan, baik yang dilakukan oleh guru kepada siswa maupun dilakukan siswa kepada sesama siswa, terjadi di semua sekolah yang diteliti. Bentuk kekerasan meliputi bullying verbal, psikologis, serta fisik. Diduga bahwa banyak pihak yang belum menyadari bahwa tindakan yang dilakukannya merupakan suatu bentuk bullying. Hingga saat ini angka kejadian bullying di Kota Mataram tidak diketahui dan dianggap rendah. Oleh karena itu, penting untuk melakukan skrining dan mengedukasi masyarakat terutama siswa sekolah tentang bullying dan pencegahannya. Tim penulis memilih 5 (lima) SMA Negeri di Kota Mataram untuk dilakukan skrining dan edukasi. Pada masing-masing SMA Negeri yang terpilih, skrining dilakukan dengan wawancara terstruktur kepada Kepala Sekolah, Focus Group Discussion (FGD) kepada 5 (lima) orang guru, dan memberikan kuisioner kepada beberapa siswa tentang bullying. Berikutnya dilakukan edukasi dalam bentuk penyuluhan kepada siswa mengenai bullying.
\end{abstract}

Kata Kunci: Skrining, Edukasi Pencegahan Bullying

\section{Pendahuluan}

Bullying telah dikenal sebagai masalah sosial yang terutama ditemukan di kalangan pelajar. Dalam beberapa tahun terakhir, fenomena bullying semakin mendapat perhatian banyak pihak, baik peneliti, pendidik, organisasi perlindungan, dan tokoh masyarakat (Rudi, 2010). Kebanyakan perilaku bullying terjadi secara tersembunyi (covert) dan sering tidak dilaporkan, sehingga kurang disadari oleh kebanyakan orang (Glew, Rivara, \& Feudtner, 2000).

Beberapa penelitian mengenai bullying yang dilakukan pada anak-anak usia sekolah menengah di beberapa negara dengan pendapatan yang tinggi menunjukkan prevalensi bullying yang cukup tinggi, yaitu antara 5-57\%, sedangkan pada negaranegara dengan pendapatan menengah atau rendah prevalensi bullying didapatkan lebih tinggi lagi, yaitu sekitar 12-100\% (Fleming, 2009). Nansel dan kawan-kawan di tahun 2001 melakukan penelitian terhadap 15.600 siswa kelas 6 sampai kelas 10 di Amerika, dan hasilnya menunjukkan sekitar 10,6\% dari mereka melaporkan menjadi korban bullying dengan frekuensi kadang-kadang dan sering selama masa sekolah, $13 \%$ mengaku melakukan bullying pada orang lain dengan frekuensi kadang-kadang dan sering, dan 6,3\% dari seluruh sampel menjadi pelaku dan korban bullying (Khairiyah, 2015).

Berdasarkan studi Ndetei dan kawan-kawan pada tahun 2007, perilaku bullying juga terjadi di sekolah menengah. Bentuk bullying yang banyak terjadi adalah dengan memukul, mengejek, 
memanggil nama panggilan, mengancam, dan mengambil barang milik korban. Perilaku tersebut dilakukan secara berulang-ulang dan berkelanjutan. Keadaan ini akan terus berlangsung karena korban tidak berani untuk melawan. Dampak dari perilaku bullying dapat menyebabkan korban merasa malu, tertekan, perasaan takut, sedih dan cemas. Jika kondisi ini berkepanjangan bisa mengarah ke depresi (Okoth, 2014). Selain dampak dari masalah psikologis juga dapat berpengaruh terhadap masalah kesehatan fisik seperti memar pada daerah yang dipukul, lecet, bengkak, sulit tidur, nafsu makan menurun. Gejala lain yang dimunculkan diantaranya merasa terancam, sulit berkonsentrasi, penurunan prestasi akademik dan merasa sendiri (Laeheem, 2013). Bullying juga dihubungkan dengan angka bunuh diri yang tinggi di kalangan remaja (Center for Desease Control and Prevention, 2016).

Beberapa penelitian mengenai bullying melaporkan berbagai dampak negatif yang ditimbulkannya dengan tingkat keparahan yang bervariasi. Ketika terjadi peristiwa bullying, pelaku dan korban sama-sama merupakan elemen kunci yang perlu mendapatkan perhatian khusus. Pelaku bullying pada umumnya memiliki ciri khas, yaitu agresivitas yang tinggi dan kurang memiliki empati. Mereka cenderung menampilkan perilaku negatif dan antisosial (misalnya, membolos, nakal, penyalahgunaan zat) selama masa remaja dan berisiko untuk mengalami gangguan kejiwaan (Gini, 2008).

Bagi korban bullying, sekolah dapat menjadi tempat yang tidak menyenangkan dan berbahaya. Ketakutan yang mereka alami dapat menimbulkan depresi, low self esteem (LSE), dan sering absen. Biasanya korban bullying akan mengalami perubahan perilaku, seperti: sering menyendiri, menarik diri dari pergaulan dengan teman sebayanya (peer group), dihantui perasaan takut jika berhadapan dengan guru, semangat dan motivasi belajar menurun, serta penurunan daya kreativitas. Semua ini tentu saja akan berpengaruh pada menurunnya prestasi belajar siswa. Korban bullying merasakan berbagai emosi negatif (marah, dendam, kesal, tertekan, takut, malu, sedih, tidak nyaman, terancam), namun mereka tidak berdaya menghadapinya. Dalam jangka panjang emosiemosi ini dapat berujung pada munculnya perasaan bahwa dirinya tidak berharga. Oleh karena itu, di sebagian besar negara barat, bullying dianggap sebagai hal yang serius karena cukup banyak penelitian yang menunjukkan bahwa dampak dari perilaku ini sangat negatif (Kyriakides, 2006; Huraerah, 2007).

Bullying merupakan tindakan kekerasan yang dilakukan secara berulang dan melibatkan adanya kekuatan fisik antara korban dan pelaku. Di Indonesia, Komisi Perlindungan Anak Indonesia (KPAI) merilis data bahwa kasus bullying pernah dialami sekitar 87,6 \% anak usia 12 tahun hingga 17 tahun dimana korban laki-laki lebih banyak dari perempuan dan perilaku bullying lebih rentan terjadi pada usia remaja awal (Desiree, 2013; Aisiyai, 2015; Yani et al, 2016). Bullying yang terjadi di Indonesia banyak ditemukan di lingkungan sekolah baik formal maupun non formal. Menurut penelitian terdahulu kasus bullying yang sering terjadi sekitar $61-73 \%$ dalam bentuk kekerasan, pemerasan, mengancam dan mengambil barang-barang, selebihnya merupakan kasus bullying dalam bentuk yang lain seperti cyber bullying.

Namun demikian, dari hasil penelitian dari beberapa negara, angka kejadian bullying di Indonesia termasuk rendah jika dibandingkan negara-negara lain. Persentase siswa sekolah berusia 13-17 tahun yang mendapatkan bullying hanya sebesar $20,6 \%$, sementara persentase di negara-negara Asia Tenggara lain berkisar 36,2\% (Center for Desease Control and Prevention, 2015). Namun demikian masih sedikit informasi yang dapat digali terkait bullying di Indonesia sehingga perlu dilakukan skrining dan edukasi yang tepat untuk mengetahui masalah ini.

Di Indonesia, terdapat laporan yang terbatas dan saling bertolak belakang mengenai kejadian bullying. Di satu sisi dilaporkan mayoritas anak pernah mengalami bullying, namun dari data penelitian-penelitian lain dikatakan angka bullying di Indonesia termasuk rendah dibanding negara lain. Diduga bahwa banyak pihak yang belum menyadari bahwa tindakan yang dilakukannya merupakan suatu bentuk bullying. Demikian pula di Kota Mataram. Hingga saat ini angka kejadian bullying di Kota Mataram tidak diketahui dan dianggap rendah. Belum ada data resmi terkait bullying di Kota Mataram. Oleh karena itu, penting untuk melakukan skrining terhadap kejadian bullying pada lingkungan sekolah di Kota Mataram dan mengedukasi masyarakat terutama siswa sekolah tentang bullying dan pencegahannya. 
Penelitian ataupun data-data dari pihak sekolah dan Dinas Pendidikan dan Kebudayaan Provinsi NTB mengenai kejadian bullying di Kota Mataram tidak didapatkan. Selama ini angka kejadian bullying di Kota Mataram dianggap rendah. Istilah bullying sendiri sebetulnya baru marak digunakan pada beberapa tahun terakhir dan selama ini belum terdapat tata tertib maupun aturan dari pemerintah pusat yang khusus mengatur masalah bullying. Diduga bahwa banyak pihak yang belum menyadari bahwa tindakan yang dilakukannya merupakan suatu bentuk bullying, termasuk dari pihak guru dan civitas akademik lain di sekolah. Jika tidak terdapat tindak lanjut mengenai hal ini, dikhawatirkan bullying dapat menjadi fenomena gunung es yang siap meletus sewaktu-waktu dengan tiba-tiba muncul kasus berat yang sudah sulit ditangani.

Seperti yang telah dijelaskan sebelumnya, data mengenai bullying di Kota Mataram masih belum ada. Selama ini angka kejadian bullying di Kota Mataram dianggap rendah dan tidak menjadi masalah. Namun demikian perlu diwaspadai adanya fenomena gunung es yang sewaktu-waktu dapat mencuat ke permukaan terkait kasus bullying ini, mengingat trend angka kejadian bullying di negaranegara tingkat ekonomi rendah dan menengah cenderung bergerak naik. Salah satu tempat yang diduga banyak terdapat kasus bullying adalah lingkungan sekolah menengah. Oleh karena itu perlu dilakukan suatu skrining dan edukasi mengenai bullying di lingkungan sekolah menengah. Penulis dan tim dalam hal ini mengusulkan dilakukannya skrining mengenai kejadian bullying di SMA Negeri di Kota Mataram, yang dilanjutkan dengan edukasi tentang bullying terhadap siswa SMA Negeri di Kota Mataram tersebut.

\section{Metode Pelaksanaan}

Tujuan dari kegiatan ini adalah: 1) Skrining untuk mengetahui kasus-kasus bullying yang selama ini tidak terdeteksi di SMA Negeri di Kota Mataram. 2) Memberikan pengetahuan tentang bullying, yang meliputi definisi, faktor resiko, macam-macam bentuk dan cara, dampak, serta cara pencegahan bullying khususnya di lingkungan SMA di Kota Mataram. 3) Mencegah atau mengurangi angka kejadian bullying di SMA Negeri di Kota Mataram.

Manfaat kegiatan ini adalah: 1) Dapat diketahui angka kejadian bullying di SMA Negeri di Kota Mataram. 2) Dapat diketahui tingkat pengetahuan dasar civitas akademik SMA Negeri di Kota Mataram mengenai bullying. 3) Meningkatkan pengetahuan siswa dan civitas akademik SMA Negeri di Kota Mataram mengenai bullying. 4) Menekan angka kejadian bullying di SMA Negeri di Kota Mataram. 5) Menjadi dasar terbentuknya aturan, protap, atau tata tertib yang mendukung pencegahan bullying di sekolah.

Pada tahap persiapan, tim pengabdian melakukan telusur pustaka tentang kondisi bullying di Indonesia pada umumnya dan di Mataram pada khususnya. Kemudian tim pengabdian memilih 5 (lima) SMA Negeri di Kota Mataram dengan karakteristik prestasi akademik, latar belakang tingkat ekonomi, dan latar belakang sosial budaya yang heterogen. Selanjutnya tim menyiapkan materi, alat-alat dan bahan yang diperlukan untuk skrining bullying. Materi yang disiapkan meliputi: a) Pembuatan kuisioner untuk wawancara mendalam (in-depth interview) kepada kepala sekolah, b) Pembuatan kuisioner untuk focused group discussion (FGD) kepada perwakilan guru.

Pada tahap intervensi, tim turun ke lapangan bersama-sama dan melakukan skrining dengan metode yang telah disiapkan secara bersama-sama sebagai satu kesatuan, tidak membagi diri. Setiap kegiatan wawancara mendalam dan FGD dilakukan oleh semua tim pengabdian, dimana anggota tim ada yang bertugas sebagai moderator, notulen, dan observer. Kegiatan wawancara mendalam dan FGD juga menggunakan alat bantu tape recorder agar hasil wawancara dan FGD tidak ada yang terlewat dari pengamatan tim pengabdian. Dari hasil skrining, jika terdapat siswa yang terindikasi mengalami bullying (korban), atau melakukan bullying (pelaku) akan diberikan waktu untuk berkonsultasi kepada psikiater yang juga menjadi tim pengabdian.

Pada hari berikutnya yang telah ditetapkan, dilakukan edukasi kepada siswa pada khususnya, dan civitas akademik SMA pada umumnya mengenai bullying dalam bentuk penyuluhan dan diskusi aktif. 


\section{Hasil dan Pembahasan}

Negeri di Kota Mataram dengan karakteristik prestasi akademik, latar belakang tingkat ekonomi, dan sosial budaya yang heterogen yang akhirnya dipilih menjadi tempat kegiatan pengabdian masyarakat ini. Kelima SMU tersebut adalah SMU Negeri 3 Mataram, SMU Negeri 4 Mataram, SMU Negeri 6 Mataram, SMU Negeri 7 Mataram, dan SMU Negeri 8 Mataram.

Kegiatan wawancara mendalam (in-depth interview) kepada masing-masing kepala sekolah dan kegiatan Focus Group Discussion (FGD) kepada perwakilan para guru di lima SMU Negeri yang dipilih telah dilakukan pada tanggal $6-10$ Mei 2018. Perwakilan guru yang dipilih untuk FGD di tiap sekolah terdiri atas: 1) 1 orang guru wali kelas, 2) 1 orang guru PPKN, 3) 1 orang guru Pendidikan Agama, 4) 1 orang guru Bimbingan dan Konseling, dan 5) 1 orang guru pembina UKS. Total terdapat 5 orang kepala sekolah yang diwawancarai, dan 25 orang guru yang berpartisipasi dalam FGD. Wawancara mendalam dan FGD bertujuan menilai persepsi dan tingkat pengetahuan guru dan kepala sekolah akan bullying sekaligus sebagai skrining angka kejadian bullying di sekolah.

Dari hasil wawancara mendalam dan FGD didapatkan semua guru dan kepala sekolah telah mengenal istilah bullying, namun sebagian guru dan kepala sekolah masih menganggap kejadian bullying terbatas pada kegiatan menyakiti orang lain secara fisik saja. Kepala sekolah dan guru mendapatkan pemahaman mengenai bullying melalui media sosial, brosur, leaflet, dan pelatihan yang pernah diadakan Departemen Pendidikan dan Kebudayaan. Sebagian guru dan kepala sekolah dapat mengenali faktor-faktor risiko seorang siswa menjadi korban bullying, yaitu jika terdapat perbedaan kondisi pada siswa yang bersangkutan dibanding rata-rata kondisi siswa lain, misalnya terdapat gangguan fisik (lebih pendek, lebih gemuk, gangguan pendengaran, dan lain-lain), perbedaan status ekonomi, perbedaan kultur, dan latar belakang lain. Sebagian besar guru dan kepala sekolah belum mengenali kecenderungan seseorang untuk menjadi pelaku bullying. Terdapat kurang dari 15 kasus bullying di kelima SMU Negeri di Kota Mataram yang terdeteksi, tetapi semua kasus dapat diselesaikan di tingkat sekolah.
Sebagian besar guru dan kepala sekolah dapat mengenal tanda dan gejala yang umumnya dialami korban bullying. Korban bullying umumnya menarik diri, menjadi pendiam, mengalami penurunan prestasi akademik, terdapat bukti bekas tanda-tanda kekerasan fisik, hingga menolak pergi ke sekolah. Akan tetapi para guru dan kepala sekolah merasa sulit mendeteksi pelaku bullying dan menganggap pelaku bullying dapat siapa saja. Semua guru dan kepala sekolah sepakat bahwa bullying dapat memberikan dampak yang merugikan di masa depan bagi siswa yang mengalaminya secara fisik maupun mental.

Para guru dan kepala sekolah menganggap terdapat faktor protektif di sekolah-sekolah di SMU Negeri di Kota Mataram yang dapat menghambat terjadinya bullying. Faktor-faktor tersebut meliputi adanya mata pelajaran PPKN dan pendidikan agama, dimana siswa diajarkan tentang bertoleransi terhadap perbedaan, berbuat baik dan tidak menyakiti terhadap sesama sebagai bagian ketakwaan terhadap Tuhan. Selain itu terdapat peran wali kelas yang diharapkan dapat mendeteksi sejak dini jika terdapat kasus bullying di kelas. Adanya UKS dan guru bimbingan dan konseling juga diharapkan menjadi pintu skrining untuk mendeteksi adanya kasus-kasus bullying dan dapat menyelesaikan kasus bullying yang terjadi sehingga tidak terjadi dampak jangka panjang.

Kegiatan selanjutnya berupa pelaksanaan edukasi pencegahan bullying dilakukan dengan cara penyuluhan mengenai bullying kepada perwakilan siswa di kelima SMU Negeri di Kota Mataram tersebut. Kegiatan penyuluhan dilaksanakan pada Hari Sabtu, 12 Mei 2018. Hari Sabtu dipilih karena merupakan hari dengan jam pelajaran yang lebih sedikit sehingga diharapkan tidak mengganggu jadwal akademik siswa. Siswa yang dipilih mengikuti penyuluhan adalah perwakilan dari siswa kelas 10 dengan pertimbangan siswa kelas 10 mempunyai cukup waktu untuk diberikan materi penyuluhan, sementara siswa tingkat yang lebih atas pada saat itu sedang fokus untuk menghadapi ujian akhir. Siswa kelas 10 juga masih mempunyai masa sekolah yang masih panjang di SMU tersebut dan diharapkan dengan pemberian bekal materi bullying sejak dini dapat menjadi bekal lebih dini untuk mencegah terjadinya bullying di sekolah. Peserta penyuluhan di SMU 3 terdiri dari 34 siswa, SMU 4 terdiri dari 34 siswa, SMU 6 terdiri dari 32 
siswa, SMU 7 terdiri dari 34 siswa, dan SMU 8 terdiri dari 32 siswa. Kegiatan penyuluhan diawali dengan pemberian pretes dan diakhiri dengan pemberian postes kepada peserta setelah penyuluhan berakhir. Diapatkan perbaikan nilai pada postes dibandingkan dengan nilai pretes dimana nilai rata-rata pretes 5,92 dan nilai rata-rata postes 8,13 pada kelima SMU Negeri di Kota Mataram.

Materi penyuluhan meliputi definisi bullying, faktor-faktor risiko yang membuat seseorang rentan mengalami bullying, individu yang terlibat (pelaku dan korban), patofisiologi terjadinya bullying, dampak bullying, bagaimana tata laksananya dan bagaimana strategi mencegah bullying. Penyuluhan dilakukan secara interaktif antara pemberi materi dengan peserta dengan media presentasi power point dan bersifat pemaparan materi yang diikuti dengan diskusi interaktif. Proses penyuluhan dimulai dari jam 08.00 WITA ditandai dengan dimulainya pretes dan diakhiri pada jam 13.00 WITA ditandai dengan selesai dilakukannya postes kepada peserta.

\section{Kesimpulan}

Bullying merupakan masalah sosial yang sering ditemukan, terutama di kalangan pelajar. Bullying dapat memberikan dampak buruk yang berat pada korban berupa gangguan belajar, gangguan mental, gangguan fisik, dan masalah kesehatan serta psikososial lain. Di beberapa negara, bullying berkontribusi besar terhadap angka kejadian bunuh diri pada remaja. Dari kegiatan pengabdian masyarakat di SMU Negeri di Kota Mataram ini, didapatkan data bahwa kepala sekolah dan guru di SMU Negeri di Kota Mataram cukup mengenal bullying, mengetahui faktor-faktor risiko yang mungkin membuat siswa rentan mengalaminya, dapat mengenal tanda dan gejala korban bullying, dan sampai saat ini dapat mengatasi kasus-kasus bullying yang terjadi di sekolah. Namun demikian, kewaspadaan dan deteksi dini terhadap kejadian bullying perlu ditingkatkan.

Terdapat beberapa faktor protektif yang dapat mencegah terjadinya bullying di lingkungan sekolah di Indonesia. Faktor-faktor tersebut meliputi adanya mata pelajaran PPKN, Pendidikan
Agama, tersedianya layanan bimbingan dan konseling, serta layanan UKS yang dapat mendeteksi tanda dan gejala bullying pada siswa. Faktor-faktor ini perlu dipertahankan dan juga digunakan sebagai media untuk pencegahan dan penyelesaian kasus bullying yang sudah terlanjur terjadi.

Dari hasil edukasi kepada siswa melalui penyuluhan, didapatkan nilai rata-rata pretes 5,92 dan nilai rata-rata postes 8,13 yang berarti terdapat peningkatan pengetahuan dasar siswa terhadap bullying.

\section{Saran}

Berdasarkan hasil kegiatan ini, direkomendasikan kepada pihak sekolah dan Dinas Pendidikan dan Kebudayaan Provinsi NTB untuk menambah informasi dan pengetahuan terkait bullying kepada tenaga pendidik maupun siswa sejak awal masa sekolah. Informasi dan pengetahuan yang cukup tentang bullying akan mengurangi risiko gangguan fisik maupun mental sebagai dampak jangka panjang dari bullying.

\section{Daftar Pustaka}

Gini G, Pozzoli T, 2009. Association Between Bullying and Psychosomatic Problems: A Meta-analysis. Pediatrics ; 123: p.1059-1065 www.pediatrics.org

Rudi T, 2010. Informasi Perihal Bullying. Indonesian Anti Bullying

Glew G, Rivara F, \& Feudtner C, 2000. Bullying: Children Hurting Children. Pediatrics in Review; $21 ; 183:$ p.1-10.

Huraerah A, 2007. Child Abuse (kekerasan terhadap anak), Bandung: Nuansa.

Kyriakides L, Kaloyirou C, Lindsay G, 2006. An analysis of the Revised Olweus Bully/Victim Questionnaire Using the Rasch Measurement Model. British Journal of Educational Psychology. 76, p.781-801 www.bpsjournals.co.uk

Sejiwa Foundation, 2010. Penelitian mengenai kekerasan di sekolah, April 2008. 
Khairiyah S. 2015. Korelasi antara Perilaku Bullying dan Tingkat Self-Esteem pada Pelajar SMPN di Surabaya.

Centers for Disease Control and Prevention. 2016. Understanding Bullying Factsheet 2016. Available from: https://www.cdc.gov/violenceprevention/pdf/b ullying_factsheet.pdf 